\title{
Erratum to: Infections et inflammations
}

\section{Erratum to: Infections and inflammations}

\author{
J.-L. Diehl • D. Borgel · P. Gaussem ・ D. Smadja
}

C SRLF et Springer-Verlag France 2013

Erratum to: Réanimation DOI 10.1007/s13546-012-0584-4

Une erreur s'est glissée dans l'abstract SP148, paru dans le supplément 1 du volume 22 intitulé : «Livre des abstracts, $41^{\mathrm{e}}$ congrès international de la SRLF, 16-18 janvier 2013, CNIT, Paris ».

La référence 1 correcte est :

Borgel D, Clauser S, Bornstain C, et al (2006) Elevated growth-arrest-specific protein 6 plasma levels in patients with severe sepsis. Crit Care Med 34:219-22 